\title{
COMPARATIVE STUDIES ON PHYTOCHEMICAL SCREENING OF FOUR DIFFERENT FLOWERS - COUROUPITA GUIANENSIS, BAUHINIA PURPUREA, STENOLOBIUM STANS, AND PLUMERIA RUBRA
}

\author{
SAI NANDHINI R*, NIRMALA NITHYA R \\ Department of Biotechnology, Vel Tech Rangarajan Dr. Sagunthala R\&D Institute of Science and Technology, Chennai, Tamil Nadu, India. \\ Email: sainandhini@veltech.edu.in
}

Received: 21 August 2019, Revised and Accepted: 26 September 2019

ABSTRACT

Objective: The present study aims to investigate the phytochemical from the aqueous and methanol flower extracts of four significant medicinal plants, namely, Couroupita guianensis, Bauhinia purpurea, Stenolobium stans, and Plumeria rubra.

Methods: The different flowers such as C. guianensis, B. purpurea, P. rubra, and S. stans were collected from Avadi and Koyambedu market, Chennai. Standard procedure was followed for the qualitative analysis of phytocompounds.

Results: Preliminary phytochemical analysis resulted that the methanolic flower extract of four plants has rich bioactive compounds comparably to the aqueous flower extracts. Tannins, saponins, flavonoids, terpenoids, and steroids were highly present in B. purpurea compared the other three flowers. Only plant $P$. rubra contains the rich source of cardiac glycosides in methanolic flower extract.

Conclusion: From the results of the current study, we conclude that the methanolic extract of B. purpurea flower has bulk phytocompounds and can be used as a traditional medicine to treat a variety of diseases.

Keywords: Secondary metabolites, Phytocompounds, Therapeutic, Pharmaceutical, Medicinal plants.

(c) 2019 The Authors. Published by Innovare Academic Sciences Pvt Ltd. This is an open access article under the CC BY license (http://creativecommons. org/licenses/by/4. 0/) DOI: http://dx.doi.org/10.22159/ajpcr.2019.v12i11.35423

\section{INTRODUCTION}

In ancient times, higher plants possess a rich source of medicinal compounds for human diseases [1]. Medicinal plants contain phytochemicals which protect from various diseases [2]. The usage of medicinal plants in the system of medicine, i.e. Ayurveda, Siddha, and Unani is well known [3]. Based on utilization of flowering plants are reported to have plenty of secondary metabolites [4]. Secondary metabolites are called phytochemicals, biologically active compounds to protect from diseases [5]. Plants have given rise to some important drugs which are in use today, and it provides daily needs such as food and shelter for man [6]. Couroupita guianensis belongs to Lecythiaceae family; it is native to Northern South America and Southern Caribbean, and India. This plant is used for drug preparation to cure bleeding piles, dysentery, scorpion poison, and gastritis [7]. C. guianensis flower is used to treat hypertension, tumors, skin diseases, wound, cold, stomach ache, and malaria. Various parts of the tree have been reported to contain volatile oils, ketosteroids, glycosides, couroupitone, indirubin, isatin, and phenolic substances [8]. Bauhinia purpurea belongs to Fabaceae family, consists of 15 species all over India [9]. The different parts of the plant used to treat blackness of lip or tongue, convolution, thigh swelling, and rheumatism [10-13]. Stenolobium stans called as Tecoma stans, yellow bells and Ginger Thomas belong to Bignoniaceae family. S. stans flower is used as a treatment for stomach pains, diabetes, and digestive problems [14]. It has antidiabetic, anticancer, antioxidant, antimicrobial, and antifungal properties. These plants are fast-growing with 20-30 ft in height, having a moderate growth, and yellow flowers. Fruits are elongated and clustered. The plant is in use through Mexico, India, and Central America for diabetes, roots for diuretic and urinary disorder control [15]. Plumeria rubra is also called red frangipani, temple tree belongs to Apocynaceae family. This plant is native to Mexico and used to treat diabetes mellitus. It has now been established that the plants synthesize and accumulate some secondary metabolites such as alkaloids, glycosides, tannin, and volatile oil. P. rubra leaves are still used as a treatment for ulcers, leprosy, and inflammations [16]. The essential oil from the P. rubra flowers is used for perfumery and aromatherapy purposes [17].

The present study aims to comparatively analyze various important phytochemicals present in the flower extracts of four selected medicinal plants, prepared as aqueous extract and methanol extract separately.

\section{METHODS}

\section{Collection of flowers}

The different flowers such as C. guianensis, B. purpurea, P. rubra, and $S$. stans were collected from Avadi and Koyambedu market, Chennai.

\section{Preparation of flower extract}

After the collection of flowers, it was washed with double distilled water and shade dried to evaporate the water molecules present in it. The dried flowers were ground into a fine powder and preserved in an air-sealed polythene cover for further evaluation.

\section{Preparation of aqueous extract and crude alcohol}

$10 \mathrm{~g}$ of four different powdered flower samples was taken in eight different containers, and $100 \mathrm{ml}$ of water and ethanol has been added in every four individual containers. The sample was held for $24 \mathrm{~h}$, filtered through Whatman filter paper, and dried.

Phytochemical screening of flower extract

The methanol and aqueous flower extract solutions were analyzed for the presence of the phytochemical analysis by the following standard procedure [18-20].

\section{Test for tannins}

$0.4 \mathrm{ml}$ of flower extract was dissolved in ferric chloride. A solution was changed to dark green color; it indicates the presence of tannins. 
Table 1: Comparative analysis of phytochemicals in the aqueous flower extract of Couroupita guianensis, Bauhinia purpurea, Plumeria rubra, and Stenolobium stans

\begin{tabular}{|c|c|c|c|c|}
\hline Name of the test & $\begin{array}{l}\text { Couroupita guianensis } \\
\text { flower extract }\end{array}$ & $\begin{array}{l}\text { Bauhinia purpurea } \\
\text { flower extract }\end{array}$ & $\begin{array}{l}\text { Plumeria rubra } \\
\text { flower extract }\end{array}$ & $\begin{array}{l}\text { Stenolobium stans } \\
\text { flower extract }\end{array}$ \\
\hline Test for tannins & + & ++ & + & + \\
\hline Test for saponins & ++ & + & - & ++ \\
\hline Test for flavonoids & + & + & + & + \\
\hline Test for terpenoids & + & + & - & - \\
\hline Test for steroids & - & - & - & - \\
\hline Test for cardiac glycosides & - & - & - & - \\
\hline
\end{tabular}

+: Present, ++: Present in bulk, -: Absent

Table 2: Comparative analysis of phytochemicals in the methanol flower extract of Couroupita guianensis, Bauhinia purpurea, Plumeria rubra, and Stenolobium stans

\begin{tabular}{|c|c|c|c|c|}
\hline Name of the test & $\begin{array}{l}\text { Couroupita guianensis } \\
\text { flower extract }\end{array}$ & $\begin{array}{l}\text { Bauhinia purpurea } \\
\text { flower extract }\end{array}$ & $\begin{array}{l}\text { Plumeria rubra } \\
\text { flower extract }\end{array}$ & $\begin{array}{l}\text { Stenolobium stans } \\
\text { flower extract }\end{array}$ \\
\hline Test for tannins & + & ++ & + & + \\
\hline Test for saponins & ++ & + & - & ++ \\
\hline Test for flavonoids & + & + & + & + \\
\hline Test for terpenoids & - & + & - & + \\
\hline Test for steroids & + & + & - & + \\
\hline Test for cardiac glycosides & - & - & + & - \\
\hline
\end{tabular}

Test for cardiac glycosides

$0.4 \mathrm{ml}$ of flower extract was mixed in $2 \mathrm{ml}$ glacial acetic acid with one drop of $1 \%$ ferric chloride (FeCl3). A brown ring was formed between the layers; it indicates the presence of cardiac glycosides.

Test for saponins

$0.4 \mathrm{ml}$ of flower extract was mixed with $5 \mathrm{ml}$ of distilled water. The appearance of foam indicates the presence of saponins.

Test for flavonoids

$\mathrm{NaOH}$ and $\mathrm{HCL}$ were added in $0.4 \mathrm{ml}$ of flower extract. The yellow color solution changed to colorless, it indicates the presence of flavonoids.

\section{Test for steroids}

$0.4 \mathrm{ml}$ of flower extract taken up $2 \mathrm{ml}$ of acetic anhydride and $2 \mathrm{ml}$ of $\mathrm{H}_{2} \mathrm{SO}_{4}$. The color of the samples will change from violet to blue or green, indicating the presence of steroids.

\section{Test for terpenoids}

$0.4 \mathrm{ml}$ of flower extract was taken with $2 \mathrm{ml}$ of chloroform and $5 \mathrm{ml}$ of concentrated sulfuric acid was carefully added at the sides to form a layer. A reddish-brown color interface has appeared; it indicates the presence of terpenoid.

\section{RESULTS AND DISCUSSION}

In the present investigation, the aqueous and methanol extracts of different flowers such as C. guianensis, B. purpurea, S. stans, and P. rubra results in the presence of bioactive compounds and some are absent as well. The results of aqueous extract are shown in Table 1 and methanol flower extract shown in Table 2.

Methanol flower extracts show the bulk of phytocompounds compared to aqueous flower extract. Tannins, saponins, flavonoids, terpenoids, and steroids were present as the rich source in methanol extract of B. purpurea and S. stans. Cardiac glycosides were detected in methanol extract of P. rubra and it shows as negative in other three methanol and aqueous flower extracts. Tannins and flavonoids are detected in both methanol and aqueous flower extracts. C. guianensis contains a bulk form of saponins and indicates as absence in $P$. rubra. In four different aqueous flower extracts, phytocompounds such as tannin, flavonoids, and saponins are richly present, but it was weak in steroids and cardiac glycosides. Flavonoids will be easily absorbed into the cell membrane and protect the cells from damage [21]. Different phytocompounds are helped to treat the diseases, in the presence of alkaloids, it contains antitumor and anti-inflammatory [22]. Flavonoids will modify the natural biological reaction and to treat anticancer, antimicrobial, and antiallergic activities [23]. "Tannins" contain both fungicidal and bactericidal activities [24]; saponins have hypercholesterolemia and antimicrobial properties and mostly responsible for the central nervous system [25]. Cardiac glycoside properties are attributed to pharmacological activity.

\section{CONCLUSION}

Qualitative phytochemical analysis of flower extracts indicates the rich source of bioactive compounds present in the medicinal plants. From the current study, the phytochemical composition of methanol extracts shows bulk nature of phytocompounds comparably to aqueous flower extracts. In that methanol extract, B. purpurea shows the rich phytocompounds compare to the C. guianensis, S. stans, and P. rubra.

\section{AUTHORS' CONTRIBUTIONS}

Sai Nandhini has generated the idea and done the work completely and has compiled the whole manuscript; Nirmala Nithya checked the file while drafting the manuscript and provided all full-text literature.

\section{CONFLICTS OF INTEREST}

The authors declared that they do not have any conflicts of interest.

\section{REFERENCES}

1. Balunas MJ, Kinghorn AD. Drug discovery from medicinal plants. Life Sci 2005;78:431-41.

2. Wink M. Modes of action of herbal medicines and plant secondary metabolites. Medicines (Basel) 2015;2:251-86.

3. Prakash NK, Bhuvaneswari S, Sripriya N, Prameela L, Bhagya R, Radhika B, et al. Antioxidant activity of common plants of Northern Tamil Nadu, India. Int J Pharm Pharm Sci 2014;6:128-32.

4. Uniyal SK, Singh KN, Jamwal P, Lal B. Traditional use of medicinal plants among the tribal communities of Chhota Bhangal, Western Himalaya. J Ethnobiol Ethnomed 2006;2:14.

5. Rajiv P, Deepa A, Vanathi P, Vidhya D. Screening for phytochemicals and FTIR analysis of Myristica dactyloids fruit extracts. Int J Pharm 
Pharm Sci 2017:9:315-8.

6. Ashur A. Herbs are your Natural Doctor Treatment with Herbs and Plants. Egypt: Heliopolis Cario; 1986. p. 192.

7. Prashan D, Pana PK, Tripathy G. Evaluation of the immunomoulatory activity of the methanolic extract of Couroupita guianensis Aubl flowers in rats. Nat Prod Radiance 2008;8:37-42.

8. Kumar S, Chandolu A, Naresh G, Sudheer V, Veldi V, Elumalai A. A short review on therapeutic uses of Couroupita guianensis AUBL. Int Res J Pharm Appl Sci 2011;1:105-8.

9. Krishnamoorthy A, Manjunath BN, Sastri SB, Deshaprabhu YR. The Wealth of India - a Dictionary of Indian Raw Materials and Industrial Products, First Supplement Series, Raw materials. Vol. 1. New Delhi: NISCAIR; 2004. p. 119

10. Chopra RN, Nayar SL, Chopra IC. Glossary of Indian Medicinal Plants. New Delhi: Publication and Information Directorate, CSIR; 1992. p. 35.

11. Nandkarni KM. Indian Materia Medica. Vol. 1. Bombay: Popular Prakashan Pvt. Ltd.; 1995. p. 182.

12. Chatterjee A, Pakrashi SC. The Treatise of Indian Medicinal Plants. Vol. 2. New Delhi: Publication and Information Directorate, CSIR; 1992. p. 16-21.

13. Sharma HM, Devi AR, Sharma BM. Vegetable drugs used by the meitei community of Manipur. Indian J Tradit Knowl 2005;4:42.

14. Govindappa M, Sadananda TS, Channabasava R, Jeevitha MK, Pooja KS, Raghavendra B. Antimicrobial, antioxidant and phytochemical screening of Tecoma stans JUSS.EX KUNTH. J Phytol 2011;3:68-76

15. Thakur L. Identification and standardization of Tecoma stans (L.) through transverse section, photochemical investigation and powder characteristics determination of roots. Int $\mathrm{J}$ Pharm Pharm Sci 2012;3:484-6
16. Bobbarala V, Katikala PK, Naidu KC, Penumajii S. Antifungal activity of selected plant extracts against phytopathogenic fungi Aspergillus niger F2723. Indian J Sci Technol 2000;2:87-90.

17. Shaida FS, Salmy SY, Tan ML, Tengku ST. Chemical components of the essential oils from three species of Malaysian Plumeria and their effects on the growth of selected microorganisms. J Biosci 2008;19:1-7.

18. Husain N, Kumar A. Comparative study of phytochemical constituents in flower of Wedelia trilobata, Achyranthes aspera and Chrysanthemum from durg district of Chhattisgarh, India. Int J Curr Microbiol Appl Sci 2015;4:150-6.

19. Marimuthu K, Dhanalakshmi R. A study on phytochemicals in Bauhinia purpurea 1. leaf and flower. Int J Pharm Sci Rev Res 2014;29:72-6.

20. Elezabeth DV, Subramanian A. Identification of phytochemical constituents and antimicrobial activity of Indigofera suffruticosa leaves. Int J Curr Biotechnol 2013;1:6-10.

21. Hanen F, Riadh K, Samia O, Sylvain G, Christian M, Chedly A, et al. Interspecific variability of antioxidant activities and phenolic composition in Mesembryanthemum genus. Food Chem Toxicol 2009;47:2308-13.

22. Castihos TS, Giodani RB, Henriques AT, Menezes FS, Zuanazzi JA. In vitro evaluation of the antioxidant and antimicrobial activities of the montanine alkaloid. Braz J Pharmacogn 2007;17:209-14.

23. Han X, Shen T, Lou H. Dietry polyphenols and their biological significance. Int J Mol Sci 2007;8:950-88.

24. Ho KY, Tsai CC, Huang JS, Chen CP, Lin TC, Lin CC, et al. Antimicrobial activity of tannin components from Vaccinium vitis idaea L. J Pharm Pharmacol 2001;53:187-91.

25. Geroge NJ, Obot AN, Akpan AE, Obi-Egbei NO. Phytochemical and antimicrobial properties of leaves of Alchornes corifolia. E J Chem 2010;7:1071-9. 